\title{
Absorptive Capacities and Innovation in Graduated Companies from a Business Incubator in the North of Mexico
}

\author{
https://doi.org/10.3991/ijac.v11i2.7629 \\ Valeria Carolina León Ramírez ${ }^{1}$, Cecilia Lorena Velarde Flores ${ }^{1}$, Marisol Rodríguez Borbón ${ }^{1}$, Sacnicté Valdez del Río ${ }^{1}$, \\ and Marco Alberto Núñez Ramírez ${ }^{1}$ \\ ${ }^{1}$ Instituto Tecnológico de Sonora, Sonora, México
}

\begin{abstract}
The aim of this research is to identify the relationship between absorptive capacities and the generation of innovation, as well as their level of influence in companies graduated from an incubator in the north of Mexico. Through a quantitative research, correlational with a non-experimental design, a sample of $\mathbf{1 0 0}$ companies was obtained. The hypotheses of the study were partially approved, finding that the entrepreneurs were able to acquire, assimilate and transform the process of absorptive capacity, generating incremental innovation which is an intangible asset with high value for organizations.
\end{abstract}

Index Terms-absorptive capacities, innovation, business incubator

\section{INTRODUCTION}

Today, knowledge has been considered as an intangible asset, capable of generating a competitive advantage [1-2]. Its importance lies in its level of use and employment for companies [3], and it depends on a series of immaterial variables, where it is possible to highlight the absorptive capacity and innovation as a set of valuable resources for organizations [4]. The first references related to absorptive capacity describe this variable as an economic ability to absorb and use external information [5]. Later, Cohen and Levinthal [4] define it as a process of knowledge accumulation, which allows the development of different business skills, including product improvement and principles that favor the innovation.

It should be noted that, due to constant economic and social changes, the development of companies is not only based on internal knowledge. It is for this reason that it is essential to establish strategies to redesign or complement organizations through assimilable and transformed external knowledge [6].

On the other hand, in recent years, entrepreneurship has been an important part of the society development [7], which is based on the creation of something new, different and with added value [8]. This phenomenon has also been linked to the economic growth of microenterprise [9], which is very important, because according to the latest report of the National Institute of Statistics and Geography (INEGI) [10] in Mexico, 97.6\% of all enterprises are classified as micro-enterprises. Therefore, this sector represents a high proportion of economic development and employment generation of the nation [11].

However, although Mexico is considered one of the most enterprising countries in the world [12], only $53.2 \%$ of the Mexican population considers entrepreneurship as an economic development option for their life plan [13].
In addition, there is a low capacity to acquire new knowledge and to put it into practice within companies, because, according to data obtained from the National Survey on Productivity and Competitiveness of Micro, Small and Medium Enterprises (ENAPROCE), low levels of knowledge application were found within these Mexican companies during 2015 [14].

Absorptive capacities and innovation in microenterprises in the north of Mexico are very significant because they allow the development of competences of high value in this region. To develop these variables, it has emerged the business incubator of the Technological Institute of Sonora (Instituto Tecnológico de Sonora, ITSON), which has tried to support micro-enterprises in the region through the advice and incorporation of knowledge.

The incubator, which is known by the acronym IDEA (imagines, develops, undertakes and achieves), has established offices in the different cities in the north of Mexico, such as Obregon City, Guaymas, Empalme and Navojoa, where students, professors, professionals, entrepreneurs and businessmen of the region participate [15].

This is a space that provides services in the northern region of Mexico, promoting the economic and social development of the communities, with the mission of being an incubator that seeks to satisfy the needs of the community, through training services, consulting and business networks. Its main objective is to support the structuring of new self-sustainable companies, promoting an entrepreneurial and innovative culture in students, academics, universities and society [15].

Moreover, it is important to note that this incubator has obtained important recognitions. For example, the National Institute of Entrepreneurs in Mexico (INADEM), has recognized from 2013 to 2017 the business incubator of the Technological Institute of Sonora as a certified incubator through a rigorous national selection process. This process has the objective to develop and boost the economy of the north of Mexico through the advice to entrepreneurs in the opening and improvement of their companies.

In addition, since 2013 the incubator has participated in the National Program for Financing Micro Entrepreneurs from the Ministry of Economy (PRONAFIM), providing a training program to micro entrepreneurs in the northern region of Mexico. Through this series of trainings, the business incubator tries to generate improvements and development in the microentrepreneurs of the region with the training in the areas of management, financial, accounting, sales and innovation [15]. 


\section{ABSORPTIVE CAPACITIES AND INNOVATION IN GRADUATED COMPANIES FROM A BUSINESS INCUBATOR IN THE NORTH OF MEXICO}

Since 2013, more than 300 entrepreneurs located in the north of Mexico have been part of the training program of this incubator. However, there is no study that has been carried out to know the absorptive capabilities in graduate enterprises of a business incubator, nor how this knowledge has associated with innovation in this kind of organizations. From these premises, the following research question arises: How are absorptive capacities associated with innovation in graduated companies from a business incubator in the north of Mexico?

In addition to the above, the increase of knowledge can influence the generation of innovation and, in turn, innovation can generate competitive organizations [16]. Then, it is possible to observe that the absorptive capacities within the formation of entrepreneurs can influence the capacity to innovate. Therefore, a second research question is established: How do absorptive capacities influence on innovation in graduated enterprises from a business incubator in the north of Mexico?

To answer the research questions, the following hypotheses are proposed:

$H_{1}$ : Absorptive capacities are positively associated with innovation in graduated enterprises from a business incubator in the north of Mexico.

$\mathrm{H}_{2}$ : Absorptive capacities influence by a significant and positive way on innovation in graduated enterprises from a business incubator in the north of Mexico.

The relevance of this study is due to the fact that there is currently no research that measures the impact of training within this incubator program. In this way, the findings will make it possible to identify the impact on the acquisition, assimilation, transformation and exploitation of external knowledge on the innovation of the trained companies. Most of the incubation work focuses on the analysis of the level of entrepreneurship and the reasons for undertaking. However, there is a gap on the relationship between absorption capacity and innovation in emerging companies that have been in an incubation program, especially within the Mexican context.

\section{LITERATURE REVIEW}

\section{A. Absorptive capacities}

According to Zahra and George [6], absorptive capacities are a set of routines and strategic processes that allow organizations to acquire, assimilate, transform and exploit knowledge with the intention of creating value and competitive advantages. These authors propose the existence of four absorptive capacities: acquisition of knowledge, assimilation of knowledge, transformation of knowledge and exploitation of knowledge. It is important to note that these are a continuous process.

\section{B. Acquisition}

The acquisition of knowledge is the first step in the absorptive capacities process. This stage is described as the ability of the company to identify, evaluate, select and acquire useful external knowledge for the activities in the organization [6].

\section{Assimilation}

As a second step in the absorptive capacity process is the assimilation, which has been understood by different authors as the ability to analyze, process, interpret and understand the external knowledge $[6,17]$. The relevance of this phase lies in the human capital that the organization has, that is why an individual with a higher degree of specialization and experience can present a mayor degree of assimilation knowledge [18].

\section{Transformation}

In the third step of the process, is the transformation. It is defined as the ability to adapt the new knowledge to the reality and needs of the organization, through the aggregation or elimination of existing knowledge to combine with the new one, and thus, to obtain novel and radically different forms of knowledge [6].

\section{E. Exploitation}

Exploitation is the last stage of the process of absorptive capacity, which is defined as the use of the acquired knowledge and its implementation in the activities of the organization that allows redesigning the existing and encouraging the creation of new things [4, $6]$.

\section{F. Innovation}

Schumpeter [19] was one of the first authors to define a concept related to innovation. For this author, the innovation is based on the development of inventions, new methods of production, as well as the introduction of different products or services in the economic and social spheres, in order to provide alternative solutions to problems. It should be noted that this variable can be categorized according to its radical or incremental character.

\section{G. Radical Innovation}

Radical innovation is a product whose use, elements, property, processes, materials or integration differ significantly from the previous one. This cannot imply a complete eradication of the previous product allowing changes in products, characterized by a great degree of investigation and specialization [20].

\section{H. Incremental Innovation}

Incremental innovation is a minor change in products and / or processes seeking to strengthen and improve existing capabilities. Therefore, it is a product with which it is counted, which has been improved or increased [21].

\section{Relationship between absorptive capacities and innovation}

It is important that companies recognize the value of the knowledge source, as well as the relevance of the exploitation of external information, so that new knowledge allows the generation of innovation [1]. Thus, the absorptive capacity is identified as a means for the generation of innovation, which reflects a close relationship between both variables [22]. 


\section{ABSORPTIVE CAPACITIES AND INNOVATION IN GRADUATED COMPANIES FROM A BUSINESS INCUBATOR IN THE NORTH OF MEXICO}

\section{Methodology}

\section{A. Research approach and design}

The present research is quantitative type with a crosssectional and transverse scope, because it tries to associate the study variables, through the use of a nonexperimental research design [23-24].

\section{B. Study sample}

The study population of this study was 370 incubated companies by the ITSON Business Incubator, that were advised in the development, structure and improvement of their company through the incubation process, which consists of training in different areas, such as: management, financial, marketing, innovation and accounting. This process comprises a period of time between 3 and 12 months, carried out from 2014 to 2016, in Obregón City, Navojoa, Guaymas and Empalme in Sonora, Mexico, state located in the north of Mexico. That is why the population in this study are micro entrepreneurs of the region and its surroundings.

A representative sample was used subjectively [25]. Thus, in the present study 100 instruments were applied to the micro enterprises. Table I shows the characteristic of the companies surveyed.

TABLE I.

CHARACTERISTICS OF THE STUDIED COMPANIES ( $\mathrm{N}=100)$

\begin{tabular}{ccc}
\hline Characteristics & $\mathbf{N}$ & $\mathbf{\%}$ \\
\hline Company location & 67 & 57.3 \\
Obregón City & 22 & 18.8 \\
Navojoa & 10 & 8.5 \\
Guaymas & 1 & .9 \\
Empalme & & \\
Activity of the companies & 45 & 45.0 \\
Industry & 26 & 26.0 \\
Commercial & 29 & 29.0 \\
Services & & \\
Size of the companies & 100 & 100.0 \\
Micro & 85 & 72.6 \\
Participation program & 7 & 6.0 \\
PRONAFIM & 8 & 6.8 \\
INADEM & & \\
Traditional Incubation & & \\
Note. Own elaboration & & \\
&
\end{tabular}

\section{Measurement instrument}

A questionnaire composed of two segments was applied, with a total of 37 items. The first segment contains 17 items assessing absorptive capacities in four dimensions: acquisition, assimilation, transformation $\mathrm{y}$ exploitation, as suggested by Zahra and George' model [6]. While the second section comprises six items based on Subramanian and Youndt [26], where three items evaluate incremental innovation, and the other three, radical innovation. The questions are written as affirmation and are evaluated using the Likert-type scale with five points, ranging from 1 (strongly disagree) to 5 (strongly agree). For the reliability of the instrument, Cronbach's alpha analysis $(\alpha)$ was used. It was obtained favorable values for absorption capacities in the case of acquisition $(\alpha=0.745)$ and transformation $(\alpha=0.727)$; However, in the assimilation and exploitation, the obtained results were below 0.70 . On the other hand, the reliability of the innovation was $\alpha=.84$ for incremental innovation, while in the case of innovation radical, the obtained value was $\alpha=.675$.

\section{REsults}

The obtained results empirically support the hypotheses raised previously in a partially way. It should be noted that the results coincide with the ideas proposed by Liao, $\mathrm{Wu}, \mathrm{Hu}$, and Tsuei [27], for whom the absorptive capacity is a key factor in the generation of value by developing innovation. Table II shows the correlation level of the variables. As can be observed in the correlation results of the variables, acquisition and transformation -dimensions corresponding to absorptive capacities- present a higher degree of relation with significant values; contrary to what happened with the dimensions of assimilation and exploitation, which show a positive but less significant link. On the other hand, the dimension of radical innovation is not related to the other dimensions; in contrast to incremental innovation, which has a positive and significant connection with all dimensions. In this way, it is observed that the entrepreneurs acquired and partially transformed the knowledge provided by the incubator, in order to generate added value in your product / service. This has allowed them to achieve incremental innovation.

TABLE II.

CORRELATION OF VARIABLES $(\mathrm{N}=100)$

\begin{tabular}{|c|c|c|c|c|c|c|}
\hline Factor & 1 & 2 & 3 & 4 & 5 & 6 \\
\hline Acquisition & - & & & & & \\
\hline Assimilation & $.448^{* *}$ & - & & & & \\
\hline Transformation & $.359^{* *}$ & $.242^{*}$ & - & & & \\
\hline Exploitation & .192 & $.202^{*}$ & $.512^{* *}$ & - & & \\
\hline $\begin{array}{c}\text { Radical } \\
\text { innovation }\end{array}$ & . 108 & .129 & .054 & .062 & - & \\
\hline $\begin{array}{l}\text { Incremental } \\
\text { innovation }\end{array}$ & $.410^{* *}$ & $.332^{* *}$ & $.426^{* *}$ & $.293^{* *}$ & .136 & - \\
\hline
\end{tabular}

In the regression analysis -considering the incremental innovation as a dependent variable - it is observed that acquisition and transformation influence positively and significantly on this dimension, although with an explanation degree of $28 \%$. Contrary to the above, regression analysis -considering the radical innovation as a dependent variable- indicates a low value in relation to each of the dimensions of the absorptive capacity, presenting in some of them, negative values. Added to this, this partially proved $\mathrm{H}_{2}$, since it was found a certain level of influence of the independent variable on the innovation of the studied companies (See tables III-IV).

TABLE III.

REGRESSION ANALYSIS CONSIDERING THE "INCREMENTAL INNOVATION" AS A DEPENDENT VARIABLE

\begin{tabular}{lccccc}
\hline \multicolumn{1}{c}{ Factor } & B & SE & B & T & $\boldsymbol{p}$ \\
\hline Acquisition & .352 & .153 & .233 & 2.295 & .024 \\
Assimilation & .276 & .184 & .147 & 1.497 & .138 \\
Transformation & .378 & .152 & .264 & 2.479 & .015 \\
Exploitation & .111 & .136 & .083 & .817 & .416 \\
\hline \multicolumn{2}{c}{ Note. Own Elaboration. $\mathrm{R}^{2}=28}$. & & &
\end{tabular}

Note. Own Elaboration. $\mathrm{R}^{2}=28$. 


\section{ABSORPTIVE CAPACITIES AND INNOVATION IN GRADUATED COMPANIES FROM A BUSINESS INCUBATOR IN THE NORTH OF MEXICO}

TABLE IV.

REGRESSION ANALYSIS CONSIDERING TO "RADICAL I INNOVATION" AS A DEPENDENT VARIABLE

\begin{tabular}{llllll}
\hline Factor & B & SE & B & T & $\boldsymbol{p}$ \\
\hline Acquisition & .097 & .187 & .062 & 0.518 & .605 \\
Assimilation & .190 & .225 & .097 & 0.846 & .400 \\
Transformati & -.015 & .186 & -.010 & -0.082 & .935 \\
on & & & & & \\
Exploitation & .050 & .166 & .036 & .302 & .763 \\
\hline \multicolumn{5}{c}{ Note. Own Elaboration. $\mathrm{R}^{2}=21}$.
\end{tabular}

The results show that the analyzed companies in the present study meet the process' objectives of the absorptive capacity. Although they transform it, they do not fully exploit the new knowledge. Therefore, this is directly related to the ideas of Van den, Van and Volberda [3], as well as Todorova and Durisin [17], who explain that exists a combination between existing knowledge and the new one in this phase. Consequently, it produces partial or radical changes that can generate a type of innovation, influencing the development of improvements in the organization.

According to the obtained results, the 100 microenterprises analyzed present partial changes and improvements in their products / services, but they do not achieve a total transformation. Then, as Damanpour [28], Tidd, Bessant and Pavitt [29] explain, a company can perceive a new product, generating innovation in its activities; however, to others it can only be the modification of a process. Therefore, the level of innovation can be influenced by factors such as the degree of experience, infrastructure, technology, size and specialty of the subjects.

\section{CONCLUSIONS}

During the last 8 years, the incubator worked with more than 400 entrepreneurs in the north of Mexico, where it has been possible to see how absorption capacities have favored innovation. An example of this is the training received by a woman who owns a restaurant founded 20 years ago, which improved its performance and increased its sales in the last three years of activity, by integrating technology, segmenting market and creating new ice cream products. In addition, it is possible to highlight a young entrepreneur, who, at 20 years of age together with the incubator, improved his business model and currently has three companies.

It is concluded that, despite not meeting a significant degree in all phases of the absorptive capacity, it is identified that the entrepreneurs preferentially develop the acquisition and transformation of knowledge, achieving an added value or partial change in their product / service. Moreover, it is considered as an incremental innovation, which was one of the dimensions with a greater degree of significance in the correlation, favoring the validity of the model.

It should be noted, that the low degree of significance observed in the obtained results from the analysis on the dimension of radical innovation, it is explained by Tidd, Bessant y Pavitt [29]. It describes that different factors may influence the degree of innovation presented in companies, such as: a smaller infrastructure, lack of years in the specialization, and other factors that can generate an environment where innovation is present.
Therefore, the absorptive capacity is not a determinant within the innovation processes of micro-enterprises; although, the use of external knowledge allows the development in low or high degree of improvements in the organization. The results of the present study are relevant to know the behavior of organizations and the use of external knowledge in order to convert it into an intangible asset of high performance; in addition to being a cluster of information for the process improvement in the model of training and monitoring of the service provided by the business incubator.

For future studies, it could be important to consider the next recommendations: increase the sample size to register a higher degree of validity in the model, and carry out a longitudinal study that allows to know the influence of the variables. In addition, considering that absorptive capacity is not an isolated factor, so it is recommended to associate this variable with others, such as: organizational structure, company size, experience in turnover and installed capacity, to improve the phenomenon explanation. Therefore, it is expected that through the present research findings, it needs to be considered the importance of absorptive capacity and innovation as relevant issues and thus prompting a number of mayor studies in the case of the intangible value in organizations.

\section{REFERENCES}

[1] C. K. Prahalad and G. Hamel, "The core competence of the corporation”, Harvad Business Review, vol. 68, pp.79-90, 1990. http://www.stratafrica.com/media/63222d0a46a87ff0ffff81ba7f00 0101.pdfR. Nicole, "Title of paper with only first word capitalized", J. Name Stand. Abbrev., in press.

[2] E.T. Penrose, The Theory of growth of the firm, New York: Wiley, 1959.

[3] F. Van den, R.Van Wijk and H. Volberda, "Absorptive capacity: antecedents, models and outcomes", Erasmus Research Institute Management, Rotterdam, 2003. https://repub.eur.nl/pub/334/ERS2003-035-STR.pdf

[4] W. Cohen and D. Levinthal, "Absorptive capacity: a new perspective on learning and innovation", Administrative Science Quarterly, vol. 35, pp. 128-152, 1990. https:/www.uzh.ch/iou/orga/ssl-dir/wiki/uploads/Main/v28.pdf

[5] J.H. Adler, Absorptive Capacity: The concept and its determinants, Washington DC, USA: The Brookings Institution, 1965.

[6] S. Zahra and G. George, "Absorptive capacity: a review, reconceptualization, and extension", Academy of Management Review, vol. 27, pp. 185-203, 2002. http://frontiers.sauder.ubc.ca/Zahra George AMR 2002.pdf

[7] Z.J. Acs and D.B. Audretsch, The emergence of the entrepreneurial society, Stockholm, Sweden: Foundation for Small Business Research, 2001.

[8] S. Shane and S. Venkataraman, "The promise of entrepreneurship as a field of research", Academy of Management Review, vol. 25, pp. 217-226, 2000. http://doi:10.5465/AMR.2000.2791611

[9] P. Kam, Y. Ping and E. Autio, "Entrepreneurship, innovation and economic growth: Evidence from GEM data", Small Business Economics, vol. 24, pp. 335-350, 2005. https://link.springer.com/article/10.1007/s11187-005-2000-1

[10] Instituto Nacional de Estadística y Geografía INEGI, "Encuesta Nacional sobre Productividad y Competitividad de las Micro, Pequeñas y medianas empresas", 2016. http://www.inegi.org.mx/est/contenidos/proyectos/encuestas/establ ecimientos/otras/enaproce/doc/ENAPROCE 15.pdf

[11] I. Morales, "Las Pymes en México; entre la creación fallida y la destrucción creadora", Economía informa, vol. 366, pp. 39-48, 2011. $\quad$ http://biblat.unam.mx/es/revista/economia- 


\section{ABSORPTIVE CAPACITIES AND INNOVATION IN GRADUATED COMPANIES FROM A BUSINESS INCUBATOR IN THE NORTH OF MEXICO}

informa/articulo/las-pymes-en-mexico-entre-la-creacion-fallida-yla-destruccion-creadora

[12] R.W. Fairlie and C. Woodruff, Mexican entrepreneurship: $A$ comparison of self-employment in Mexico and the United States. In G. J. (Ed.), Mexican immigration to the United States, pp. 123158, Chicago: University of Chicago Press, 2007. http://www.nber.org/chapters/c0100.pdf

[13] S, Singer, J. Amorós and D. Moska, "Global Entrepreneurship Monitor, 2014 Global Report, Global Entrepreneurship Research Association, 2014. http://gemconsortium.org/report/49079

[14] Instituto Nacional de Estadística y Geografía INEGI, "Encuesta Nacional sobre Productividad y Competitividad de las Micro, Pequeñas y medianas empresas", 2015. http://www.inegi.org.mx/est/contenidos/proyectos/encuestas/establ ecimientos/otras/enaproce/default t.aspx

[15] Instituto Tecnológico de Sonora ITSON, "Incubadora de Empresas ITSON". 2018. http://www.itson.mx/iniciativas/Incubadora/Paginas/principal.aspx

[16] Z. Griliches, "The search for R\&B spillovers", Scandinavian Journal of Economics, vol. 94, pp.29-47, 1992. http://www.nber.org/papers/w3768.pdf

[17] G. Todorova and B. Durisin, "Absorptive capacity: valuing a reconceptualization", Academy of Management Review, vol. 32(3), pp. 774-786, 2007. https://miami.pure.elsevier.com/en/publications/absorptivecapacity-valuing-a-reconceptualization

[18] D.B. Minbaeva, "HRM, practices and MNC knowledge transfer", Personnel Review, vol. 34(1), pp. 125-145, 2005. https://www.researchgate.net/profile/Dana_Minbaeva/publication/ 241326407 HRM practices and MNC knowledge transfer/links 102e7e52ee69e4cfe96000000.pdf

[19] J.A. Schumpeter, Business Cycles: A Theoretical, Historical and Statistical analysis of the Capitalism Process, New York: Mc Graw-Hill1, 1939.

[20] W.J. Abernathy and K.B. Clark, "Innovation: Mapping the Winds of Creative Destruction", Research Policy, vol. 14(1), pp. 3-22, 1985. http://www.wz.uw.edu.pl/pracownicyFiles/id12236Abernathy, $\% 20$ Clark $\% 20-$

\%20Mapping $\% 20$ the $\% 20$ winds $\% 20$ of $\% 20$ creative $\% 20$ destruction .pdf

[21] J.M. Benner and M. Tushman, "Process Management and Technological Innovation: A Longitudinal Study of the Photography and Paint Industries", Administrative Science $\begin{array}{llll}\text { Quarterly, vol. } 47, \quad \text { pp. } & 676-706, & 2002 .\end{array}$ http://knowledge.wharton.upenn.edu/wpcontent/uploads/2013/09/1301.pdf

[22] N. Vermeulen, J.N. Parker and B. Penders, "Understanding life together: A brief history of collaboration in biology", Endeavour, $\begin{array}{lllll}\text { vol. } & 37 & \text { (3), } & \text { pp. } & 162-171,\end{array}$ https://doi.org/10.1016/j.endeavour.2013.03.001
[23] G. Briones, Metodología de la investigación cuantitativa en las ciencias sociales, Bogotá, Colombia: Instituto colombiano para el fomento de la educación superior, 2002.

[24] R. Hernández, C. Fernández and M. Baptista, Metodología de la investigación, México: Mc Graw Hill, 2010.

[25] J. Casal and E. Mateu, Tipos de Muestreo Revista de Epidemiología y Medicina Preventiva, Barcelona: Universidad Autónoma de Barcelona, 2003.

[26] M. Subramaniam and M.A. Youndt, "The influence of intellectual capital on the types of innovative capabilities", Academy of Management Journal, vol. 48, pp. 450-463, 2005. https://dialnet.unirioja.es/servlet/articulo?codigo $=1193409$

[27] S. Liao, Ch. Wu, D. Hu, and G. Tsuei, "Knowledge acquisition, absorptive capacity, and innovation capability: an empirical study of Taiwan's knowledge-intensive industries", International Journal of Human and Social Sciences, vol. 5(12), pp. 759-766, 2010. https://scholar.waset.org/1999.10/3757

[28] F. Damanpour, "Bureaucracy and innovation revisited: Effects of contingency factors, industrial sectors and innovation characteristics", Journal of high Technology Innovation Management, vol. 7, pp. 149-173, 1996. https://doi.org/10.1016/S1047-8310(96)90002-4

[29] J. Tidd, J. Bessant and K. Pavitt, Managing innovation: Integrating technological, market and organizational change, West Sussex, UK: John Wiley \& Sons, 2005.

\section{AUTHORS}

Valeria Carolina León Ramírez is MBA student at Instituto Tecnológico de Sonora. (valeria.leon92@hotmail.com).

Cecilia Lorena Velarde Flores is MBA student at Instituto Tecnológico de Sonora (cecilia.velarde@itson.edu.mx).

Marisol Rodríguez Borbón is an MBA student at Instituto Tecnológico de Sonora. (marisol.rodriguez@incubaitson.com).

Sacnicté Valdez del Río is with the Department of Management, Instituto Tecnológico de Sonora, Calle 5 de febrero 818 Sur, C.P. 85000, Ciudad Obregón, Sonora, México (sacnicte.valdez@itson.edu.mx).

Marco Alberto Núñez Ramírez is with the Department of Management, Instituto Tecnológico de Sonora, Calle 5 de febrero 818 Sur, C.P. 85000, Ciudad Obregón, Sonora, México (marco.nunez@itson.edu.mx).

Article submitted 29 August 2017. Resubmitted 12 March 2018. Final acceptance 04 April 2018. 